\title{
Application of V. Pareto's economic efficiency criterion in Russian judicial practice
}

\author{
Alina Dmitrievna Khokhlova ${ }^{1}$ \\ RUDN University, Law Institute, Department of Theory of Law and State, Moscow, Russia
}

\begin{abstract}
The purpose of the research is to justify the productivity of the application of one of the two most common criteria of economic efficiency (V. Pareto principle) in Russian judicial practice. Justification is carried out by identifying the content of the Pareto criterion, assessing examples of its application by Russian courts and determining the conditions and limitations of such application. The methodological basis of work was the formal-legal method, which allowed to analyze the texts of judicial decisions on the use by the court of normative economic analysis of law; the comparative method, which was used to compare the theoretical foundations and practical features of the criterion of economic efficiency by the Russian judiciary. The results of the research were the author's conclusions about the applicability of the Pareto criterion in the Russian reality and the formulation of the most likely areas of its use by the courts. Law as an object of scientific knowledge cannot be studied in isolation from its social, cultural, political and economic assumptions, as it is a central tool by which the state affects the economic well-being of society. To improve the practice of using this tool, it seems necessary to evaluate it from the standpoint of economic efficiency. In this regard, the further vector of evolution of Russian law will be more and more active use of methodological developments of economic theory, the application of the economic analysis of law developed in the United States in law enforcement practice. This leads to the need for interdisciplinary research on the conceptual and practical problems of using this direction in Russia. The novelty of the research lies in a comprehensive approach, to the problem of applicability of normative economic analysis of law in the judicial practice of the Russian Federation.
\end{abstract}

Keywords: normative economic analysis of law, economic efficiency, Pareto-efficiency, Pareto-optimality, judicial practice

\section{Introduction}

Law is a central instrument that can affect economic growth and create guarantees of property rights, a predictable tax regime, and a favorable investment climate. This role of law in economics is particularly prominent in situations of social and economic crisis [1]. R. Posner wrote that "common law judicial doctrines make economic sense" [2]. Despite the criticism of this point of view, researchers agree that a number of common law branches

${ }^{1}$ Corresponding author: khokhlova ad@rudn.ru 
still dispose to the application of economic analysis [3], and economic reasoning should be clothed in the form of legal argumentation and become legally significant [4]. The necessity of reference to economic principles and laws is reflected in the Russian judicial practice [5]. Domestic legal scholars devote their research to the problem of increasing the effectiveness of judicial decisions [6].

Research Hypothesis: the vector of evolution of Russian law will be the use of methods of its economic analysis in law enforcement practice, as it has already happened abroad [7]. The purpose of the study is to substantiate the productivity of the application of the V. Pareto criterion of economic efficiency in the resolution of disputes by Russian courts. The objectives of the study are to identify the content of the V. Pareto criterion of economic efficiency, encountered in Russian jurisprudence, and determine the conditions and limitations of its use.

\section{Methods}

The formal-legal method allowed to analyze the texts of judicial decisions on the use of normative economic analysis of law (hereinafter - EAL) by the court. Using a comparative method, the theoretical foundations and practical features of the use of the criterion of economic efficiency by Russian courts were compared.

\section{$3 \quad$ Results}

The results of the study, demonstrating the degree of applicability of the normative EAL in Russian law enforcement practice, are presented in Figure 1.

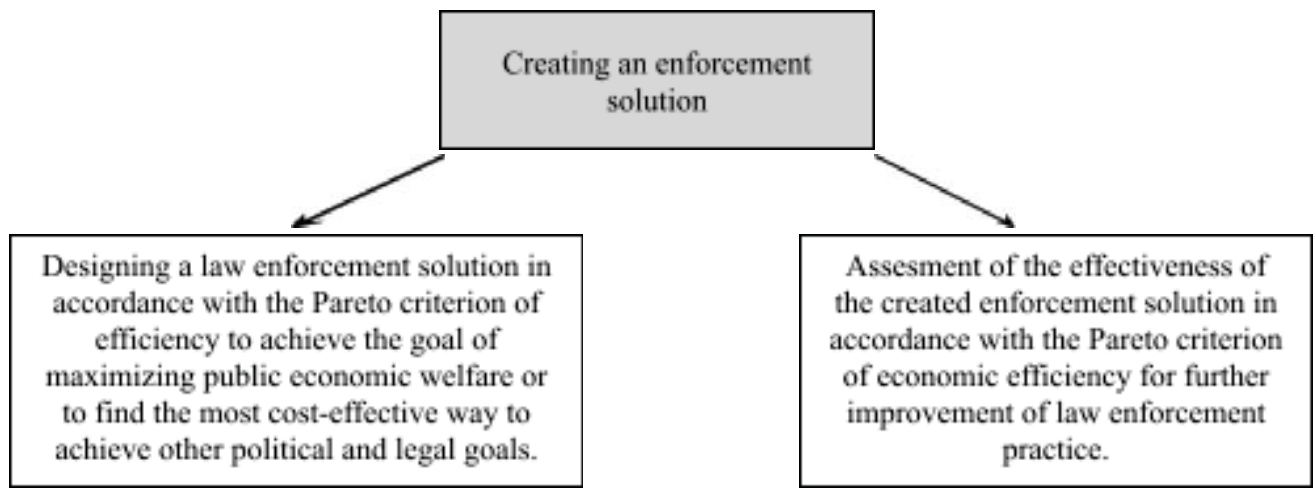

Fig. 1. The degree of applicability of the normative EAL in Russian law enforcement practice.

Table 1. Directions of reasoning based on economic efficiency criteria.

\begin{tabular}{|c|c|c|c|}
\hline \multicolumn{2}{|c|}{$\begin{array}{c}\text { Activities of higher courts: the } \\
\text { Supreme Court of the Russian } \\
\text { Federation, the Constitutional Court of } \\
\text { the Russian Federation }\end{array}$} & \multicolumn{2}{|c}{$\begin{array}{c}\text { Practice of lower courts and administrative } \\
\text { practice }\end{array}$} \\
\hline $\begin{array}{c}\text { Ex-post evaluations } \\
\text { of the practice of } \\
\text { lower courts on a }\end{array}$ & $\begin{array}{c}\text { The use of } \\
\text { economic } \\
\text { efficiency criteria }\end{array}$ & $\begin{array}{c}\text { Assessment of the facts } \\
\text { of the case: economic } \\
\text { efficiency acts as one of }\end{array}$ & $\begin{array}{c}\text { Interpretation of } \\
\text { normative } \\
\text { prescriptions: the }\end{array}$ \\
\hline
\end{tabular}




\begin{tabular}{|c|c|c|c|}
\hline $\begin{array}{c}\text { particular category } \\
\text { of cases from the } \\
\text { standpoint of } \\
\text { economic } \\
\text { efficiency in order } \\
\text { to adjust it (changes } \\
\text { in the practice of } \\
\text { interpretation of } \\
\text { legal norms in this } \\
\text { category of cases) }\end{array}$ & $\begin{array}{c}\text { in resolving cases } \\
\text { of compliance } \\
\text { with the } \\
\text { the Russian } \\
\text { Federation } \\
\text { provisions of the } \\
\text { law }\end{array}$ & $\begin{array}{c}\text { the reasons for the } \\
\text { judge's reasoning, } \\
\text { which, while taking it } \\
\text { into account, still } \\
\text { remains within the } \\
\text { framework of the } \\
\text { applicable legal rule in } \\
\text { the case }\end{array}$ & $\begin{array}{c}\text { criterion of } \\
\text { effectiveness can be } \\
\text { applied only in the } \\
\text { situation of overcoming } \\
\text { a gap/collision in the } \\
\text { law as a tool of } \\
\text { interpretation in } \\
\text { choosing one of the } \\
\text { options of interpretation } \\
\text { of the norm, because } \\
\text { the continental judge } \\
\text { cannot "create law" }\end{array}$ \\
\hline
\end{tabular}

\section{Discussion}

EAL makes it possible to predict the possible economic consequences of an enforcement decision and to penetrate into the essence and prerequisites of its creation (positive EAL). And it also offers specific models for improving law enforcement practices in order to improve their economic efficiency (normative EAL). The normative EAL is based on the fact that among the many purposes of law, (protection of morality, justice, human rights and freedoms), the economic purposes themselves (increasing the economic well-being of society) are of paramount importance. Positive EAL proposes that social well-being should be understood as the degree to which an individual's needs are met by those goods that have subjective value to him.

The first limitation to the application of the normative EAL in jurisprudence is the lack of sufficient reason to believe that economic efficiency is the main purpose of the law. This problem is reflected in the debate among proponents of normative EAL [8] and their opponents [9] over the permissibility of proclaiming the maximization of economic public welfare as the primary goal of law. Will the economically efficient solution always be fair [10] and moral? Some authors write that in many common law branches judicial decisions based on economic reasoning about efficiency seem more equitable [11]. However, there is no generally accepted answer to this question, hence it cannot be argued that economic growth stands in competition with other political-legal goals.

V. Pareto formulated his principle of the economic efficiency of the legal solution: an increase in economic welfare occurs when a part of society receives some benefit, provided that no other part of society suffers a loss. Since third parties are unable to objectively assess the subjective value of a good for a particular individual, the most effective mechanism for achieving Pareto-optimality is the creation by the state of favorable conditions for free contracting. Thus, improvement according to Pareto is achieved by a market exchange, the participants of which voluntarily increase their personal economic well-being on mutually beneficial terms. Therefore, the state in using the criterion of efficiency V. Pareto, as a minimum, should not create barriers to private transactions, and as a maximum - to form mechanisms that reduce transaction costs and thereby simplify free circulation [12, pp. 19, 129]. Examples are the creation of an effective system of judicial protection of rights arising from contractual obligations, the legislative consolidation of measures to simplify the search and verification of counterparty good faith.

In particular, A. G. Karapetov calls exchanges and auctions as an effective mechanism for achieving Pareto improvements, which "make it easier to find those who value some good above all" [13, pp. 123, 125, 129-130, 357]. Another way to achieve efficiency according to Pareto is to make power decisions of public authorities that create conditions 
for the benefit of a certain part of society, while other members of society are not harmed in any way. That is, Pareto improvements can be achieved, among other things, through the direct distribution of benefits by the state among social groups. As an example of such areas where the market, due to high transaction costs, cannot contribute to Pareto-efficiency, Posner calls legal relations connected with unintentional damage: the parties can not foresee that they will get into such a situation in advance. Therefore, they are unable to negotiate and agree. In such an environment, where the open market does not work, law "serves the purpose of ensuring the imitation of its results" [2].

In Russian law enforcement practice, the criteria of economic efficiency can be applied by the highest courts. However, Russian law enforcers are mostly guided by legal arguments, although economic logic can be traced in them. Thus, the Constitutional Court of the Russian Federation, in resolving the issue of granting legal protection to the property interests of the long-term owner on an equal basis with the interests of the owner, pointed to a different understanding of the purpose of the institute of good faith in relation to the transaction for the immediate acquisition of property rights and the good faith of the long-term owner.

The purpose of the criterion of good faith of the long-term owner, according to the Court, is the need to "protect $<\ldots .>$ public legal interests" (the return of property into civil circulation) [14]. The principle of effectiveness V. Pareto substantiates the proclamation as constitutionally significant with respect to the institute of acquisitive limitation the purpose of returning property to civil turnover, including its proper maintenance, payment of taxes. The realization of this goal is essentially aimed at ensuring economic growth, since the owner who has lost interest in the thing will gradually reduce his efforts to maximize the benefits derived from the thing, which will lead to a decrease in public economic welfare. In line with this logic, it is more effective to protect the right to the thing of the long-term owner, who appreciates it more and is able to extract more benefit from the thing, thereby achieving Pareto-improvement.

The Court also pointed to the need to harmonize public law norms with private law norms in the sphere of land relations, since the least expensive way for the state to achieve improvement on the Pareto criterion is the free market, where individuals can most objectively assess what subjective value for them is the re-registration of the existing title to the land plot. Therefore, the Court considered inadmissible: a) limitation of the right to use a land plot due to the failure to reissue the existing title, and b) automatic changes in the titles of citizens' rights to land (it must be carried out at the initiative of citizens themselves).

The use of the Pareto principle of efficiency has its drawbacks: achieving Pareto-optimality is almost impossible, and Pareto improvement is more in the private law branches. In addition, there are difficulties in objectively assessing the benefits and costs of this or that decision, given the "subjective value of the benefits, known only to their owners" [13]. V. Pareto criterion is partly idealistic, due to its "focus on the complete avoidance of negative consequences" $[15, \mathrm{pp} .55,128,131]$ and the assumption that all decisions in society will be taken unanimously by all its members, because this is the only way to reach an agreement that does not infringe on the interests of third parties.

Furthermore, even if two actors reach an agreement on a certain issue, if such an agreement restricts one party's freedom in some way (even if it is voluntary and Pareto-optimal for all its participants [16]), it cannot be considered effective, since "each individual must have the maximum amount of freedom that does not violate someone else's freedom" [2]). That is, the choice of more than two alternatives, consistent with the Pareto principle, comes into conflict with the choice based on the values of individual freedom, 
which entails the impossibility of applying this criterion in modern liberal societies [17, p. $155]$.

\section{Conclusion}

The limitation of using the Pareto criterion is due to the fact that it has only one goal which is economic growth, while negating all other goals of law. Designing an enforcement solution taking into account the V. Pareto allows us to identify cost-effective and ineffective options to achieve the goal pursued by the state. However, the final choice will be made on the basis of other criteria ("social acceptability and public utility" [18]). If in the regulated sphere of social relations due to low transaction costs it is possible to achieve a private mutually beneficial agreement and Pareto improvement, the law enforcer should not impede the functioning of the free market. If, however, a legal solution is contemplated where free contracting is not possible, the state makes a decision that distributes benefits and rights so that they fall into the hands of those who value them most. Similarly, the cost-effectiveness criterion of V. Pareto can be applied in the subsequent evaluation of the effectiveness of an already adopted enforcement solution.

\section{References}

1. S.M. Gibran, J.M. Noda, L. Locks, Relacoes Internacionais no Mundo Atual, 1(26), 123-138 (2020). https://doi: 10.21902/Revrima.v2i27.3995

2. R. Posner, Economic Analysis of Law, In 2 vols, 1, in V.L. Tambotsev (ed.) (Saint Petersburg, 2004)

3. D.D. Sokol, Notre Dame Law Review, 95(2), 795-836 (2019)

4. F. Esposito, G. Tuzet, Journal of Argumentation in Context, 9(3), 368-398 (2020). https://doi: 10.1075/jaic.19013.esp

5. Decision of the Constitutional Court of the Russian Federation of 22.06.2009. No. 10-P, Legal reference system "ConsultantPlus"

6. S.A. Kurochkin, Bulletin of Civil Procedure, 10(3), 64-88 (2020). https://doi: 10.24031/2226-0781-2020-10-3-64-88

7. C.Clarke, A. Kozinski, European Journal of Law and Economics, 48(1), 89-111 (2019). https://doi: 10.1007/s10657-019-09613-w

8. James Boyd White, Tenn. L. Rev, 54, 161-202 (1987)

9. R.M. Dworkin, Hofstra Law Review, 8, 563-590 (1980)

10. M. Prieto, Water (Switzerland), 13(3) (2021). https://doi: 10.3390/w13030278

11. D. Chavanne, Review of Law and Economics, 16(1) (2020). https://doi: 10.1515/rle-2018-0050

12. R. Cooter, T. Uhlen, Law and Economics (Academic textbook), trans. from English by D. Raskov with the participation of M. Timofeev (Publishing house "Delo" RANEPA, Moscow, 2018)

13. A.G. Karapetov, Economic analysis of law (Statute, Moscow, 2016)

14. The Decree of the Constitutional Court of the Russian Federation of 26.11.2020 No. 48-P "On case about the verification of constitutionality of point 1 of article 234 of the Civil Code of the Russian Federation in connection with the complaint of the citizen 
V.V. Volkov", Legal reference system "ConsultantPlus" (date of reference: 27.02.2021).

15. E.A. Timofeev, "Law and Economics": the doctrine of law and state in the USA in the XX century, Dissertation for the degree of Candidate of Sciences in Law (Nizhny Novgorod, 2016)

16. F. Esposito, Materiali per una Storia della Cultura Giuridica, 46(1), 225-236 (2016). https://doi: 10.1436/82985

17. A. Sen, J. Pol. Econom, 78(1), 152-157 (1970)

18. A.N. Dementiev, Bulletin of the Russian Foundation for Fundamental Research. Series: Humanities and Social Sciences, 1(98), 18-34 (2020), Accessed on: July14, 2020. [Online]. Available: https://www.elibrary.ru/item.asp?id=44116605\& 